\title{
Natural Food Availability and Assimilation in the Bivalve Choromytilus meridionalis
}

\author{
R. J. Griffiths \\ Zoology Department and Institute of Oceanography, University of Cape Town, Rondebosch 7700, South Africa
}

\begin{abstract}
Samples of seawater overlying a bed of the mussel Choromytilus meridionalis (Kr.) at Bailey's Cottage, False Bay, South Africa, were analysed for organic and inorganic content in the particle-size ranges $2-100 \mu \mathrm{m}$ and $100-200 \mu \mathrm{m}$ diameter. Organic matter comprised $10-30 \%$ of total sample weight, the remainder being predominantly sand. Changes in weight of particulate matter in samples taken throughout the year showed no clear seasonal pattern. Particulate organic material considered available as food to the mussels averaged $2.65 \mathrm{mg} \mathrm{l}^{-1}$. Particulate inorganic matter averaged twice this amount. The energy value of the organic material averaged $6.1 \mathrm{~kJ} \mathrm{~g}^{-1}$. Phytoplankton was present in $34 \%$ of the samples and is not considered an important constituent in the mussels' diet. The assimilation efficiency of mussels feeding on natural detritus averaged $40 \%$ over the ration levels $3-18 \mathrm{mg} \mathrm{l}^{-1}$ dry weight of particulate matter. However, assimilation efficiency on pure Dunaliella primolecta culture declined to zero at a ration of $3 \mathrm{mg} \mathrm{l}^{-1}$ while pseudofaeces production was initiated at $6 \mathrm{mg} \mathrm{l^{-1 }}$. It was concluded that the presence of particulate inorganic matter may be an important dietary requirement, 'diluting' the food and enabling assimilation to continue at the high ration levels experienced in the field.
\end{abstract}

\section{INTRODUCTION}

The employment of algal monocultures has greatly facilitated investigation of the feeding processes of bivalves. Much of this work has centred upon the effects of different ration levels on filtration rates and assimilation efficiencies in Mytilus edulis, and has been reviewed by Bayne et al. (1976). However, investigation of food availability in natural seawater has shown that phytoplankton cells are seldom present in sufficient numbers to contribute significantly to the mussels' diet. Authors such as Fox and Coe (1943), Jørgensen (1955) and Widdows et al. (1979) have shown that particulate organic matter is the major food source of many filter-feeding bivalves. Recently, work by Winter (1976) and Widdows et al. (1979) has centred attention on the fact that seawater in the vicinity of mussel beds frequently contains large quantities of particulate inorganic material. They have shown that suspended silt influences feeding and growth in $M$. edulis, and Widdows et al. caution on the extrapolation of laboratory experiments employing dense algal cultures to field conditions.

The filtration rates and assimilation efficiencies of Choromytilus meridionalis fed different rations of Dunaliella primolecta have been described by Griffiths (1980). In order to test the applicability of these data to field conditions, the levels of naturally available food were examined at the study site. The assimilation efficiencies of mussels feeding on organic detritus in the laboratory and field were then examined and compared with data obtained with the aid of algal cultures.

\section{MATERIALS AND METHODS}

Choromytilus meridionalis ( $\mathrm{Kr}$.) (45 mm shell length) and seawater were sampled at Bailey's Cottage, False Bay, South Africa ( $\left.34^{\circ} 06^{\prime} \mathrm{S} 18^{\circ} 28^{\prime} \mathrm{E}\right)$. A large densely packed mussel bed extends from the surf zone in the sublittoral to an average of $0.5 \mathrm{~m}$ above L.W.S. Water for analysis and experiments was collected in seawater $0.5 \mathrm{~m}$ deep immediately above the mussel bed. Data on the assimilation efficiencies of $45 \mathrm{~mm} \mathrm{C}$. meridionalis feeding on Dunaliella primolecta culture were obtained from Griffiths (1980). Widdows (1978) has shown a slight increase in assimilation efficiency of $M$. edulis with increasing body size when fed at high algal rations. However, other authors (e. g. Griffiths and King, 1979) have found assimilation efficiency to be independent of size. Although preliminary data on $C$. meridionalis show no marked affect of body size on 
assimilation, for comparative purposes only $45-\mathrm{mm}$. mussels were used in experiments presented here.

\section{Seawater Analysis}

Water was sampled between February 1978 and February 1979. The samples included two $21 \mathrm{~d}$ series of daily records during summer and winter, and 5 continuous days out of each of the remaining months. On each day $500 \mathrm{ml}$ of seawater was filtered through $200 \mu m$ and $100 \mu m$ mesh sieves and the fraction caught on the $100 \mu \mathrm{m}$ sieve, and the filtrate, were filtered through separate pre-ashed, weighed GFC filters $(25 \mathrm{~mm}$ diameter). Filtered seawater $(0.45 \mu \mathrm{m})$ was used to wash the particulate matter in the sieve onto the filter. Each filter was flushed with ammonium formate isotonic with seawater, and the dry weight and ash free dry weight $\left(450^{\circ} \mathrm{C}\right.$ for $\left.3 \mathrm{~h}\right)$ obtained. An additional $50 \mathrm{ml}$ sample was filtered onto $1 \mu \mathrm{m}$ Nucleopore filter paper and the residue gently scraped off and concentrated on a glass slide for microscopic examination. An estimate of the presence of phytoplankton in the sample was obtained by subjective assessment of the percentage of the sample volume represented by algal species.

The calorific value of seawater was obtained by filtering the $100 \mu \mathrm{m}$ fraction of $20 \mathrm{l}$ of seawater collected over the mussel bed, onto a $0.45 \mu \mathrm{m}$ Millipore filter (142 $\mathrm{mm}$ diam.). The residue on the filter was flushed with distilled water to remove salts, gently scraped from the paper with a blunt instrument, washed into a crucible with distilled water and dried at $60^{\circ} \mathrm{C}$ for $2 \mathrm{~d}$. The energy value of the particulate matter thus concentrated was measured with a Phillipson microbomb calorimeter. The ash remaining after firing (predominantly sand) was weighed and the energy value of the ash free dry weight of the sample calculated. Grinding the sample to obtain a homogeneous distribution of particulate matter reduced variability in consecutive readings of the same sample. All weighings were done on an electronic microbalance (readability $1 \mu \mathrm{g}$ ).

\section{Assimilation of Detritus in the Field}

Samples of $500 \mathrm{ml}$ of seawater collected at Bailey's Cottage were passed through a $100 \mu \mathrm{m}$ sieve. The particulate matter in the $2-100 \mu \mathrm{m}$ particle range was then concentrated onto pre-ashed, weighed GFC filters and treated as above. Simulataneous with water collection, 6 mussels were removed from the mussel bed and placed in seawater. All faeces produced within $2 \mathrm{~h}$ were concentrated onto weighed GFC filters (pre- ashed) and washed with ammonium formate. Filters were dried at $60^{\circ} \mathrm{C}$, weighed and ashed at $450^{\circ} \mathrm{C}$ for 3 $\mathrm{h}$ and weighed again. The ratio of the ash-free dry weight to dry weight of the water sample, i. e. food, and the faeces were used to determine the assimilation efficiency according to the method described by Conover (1966).

\section{Assimilation of Detritus in the Laboratory}

Mussels were allowed to feed in the laboratory on the detritus in freshly collected seawater to assess whether data comparable with that in the field (above) could be obtained. Large quantities of seawater were collected over the mussel bed each day and filtered through a $100 \mu \mathrm{m}$ sieve to eliminate large sand particles and debris. Mussels collected the previous day were placed in a recirculating constant flow system which fed water to 4 animal chambers, each of $500 \mathrm{ml}$ capacity. The flow rate exceeded $2 \mathrm{l} \mathrm{h}^{-1}$. Tests using algal culture showed that this rate was sufficiently fast to prevent depletion of food within the animal chambers. The importance of this has been discussed by Hildreth and Crisp (1976). The 201 of seawater contained within the system was changed at $0.5 \mathrm{~h}$ intervals to maintain the food concentration for the $3-4 \mathrm{~h}$ duration of the experiment. Replicate $500 \mathrm{ml}$ samples of the water prior to use, and faeces collected immediately as they were produced, were filtered onto separate preashed and weighed GFC filters and analysed as above. Faeces produced during the first hour of the experiment were discarded.

\section{RESULTS}

\section{Seawater Analysis}

The quantities of particulate organic and inorganic matter in the particle size ranges $2-100 \mu \mathrm{m}$ and 100-200 $\mu \mathrm{m}$, measured during one year, are shown in Figure 1. Organic material comprised $10-30 \%$ of the total sample weight, the remainder being predominantly sand. Widdows et al. (1979) found that organic material represented 6-25\% of the particulate matter available to Mytilus edulis in the Lynher estuary, and Verwey (1952) an average of $12 \%$ in the Wadden Sea. The organic material in the 2-100 $\mu \mathrm{m}$ range varied from $5-25 \%$ of the total sample weight. Peaks in the amount of inorganic particulate matter generally coincided with rough sea conditions.

Figure 2 shows the variation in the dry weight of particulate organic material in the $2-100 \mathrm{~cm}$ and $100-200 \mu$ range during the year. There was no clear 


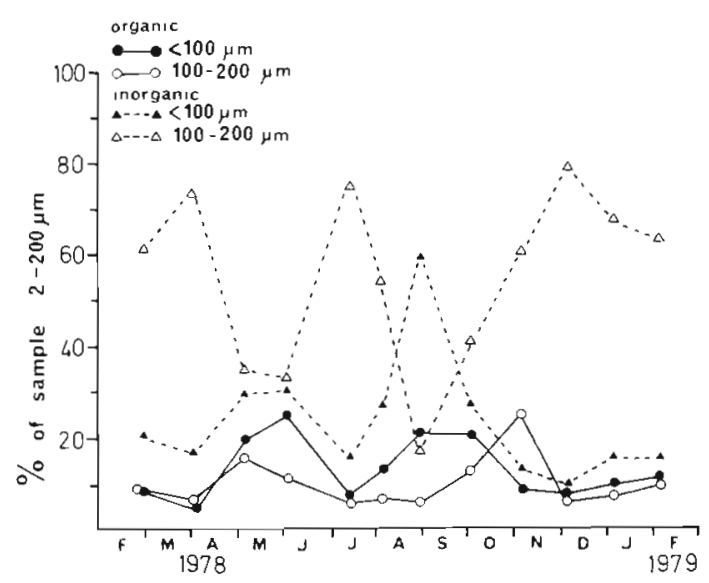

Fig. 1. Distribution of organic and inorganic matter in seawater in the particle diameter ranges $2-100 \mu \mathrm{m}$ and $100-200 \mu \mathrm{m}$; measured as $\mathrm{mg}$ dry weight $\mathrm{l}^{-1}$ and expressed as a percentage of total sample weight

seasonal pattern and the data were surprisingly constant at an average of $2.65 \mathrm{mg} \mathrm{l}^{-1}$ and $2.13 \mathrm{mg}^{-1}$, respectively. Table 1 summarises the data on the distribution of particulate organic and inorganic material. Whereas the 2-100 $\mathrm{m}$ particulate organic material was represented predominantly by free or aggregated particles in the water column, those in the 100-200 $\mu \mathrm{m}$ range were more difficult to assess. During filtering very few free particulates were seen. It was concluded that the greater portion of the organic matter in this size range was attached to the sand grains. This would be rejected in the pseudofaeces.

The origin of the detrital matter at Bailey's Cottage could not be determined. It consisted of brown irregularly shaped particles without cellular structure. From September 1978 to February 1979 the detritus was dominated by uniform particles having the appearance of faecal pellets averaging $20 \times 140 \mu \mathrm{m}$. Their origin is unknown.

A rough estimate of the presence of phytoplankton is shown in Table 2. The phytoplankters present were predominantly Nitchia and Rhizosolenia species. The latter was particularly abundant in May 1978 when it formed more than $90 \%$ of the sample. However, phytoplankton was recorded on only $34 \%$ of the days sam-

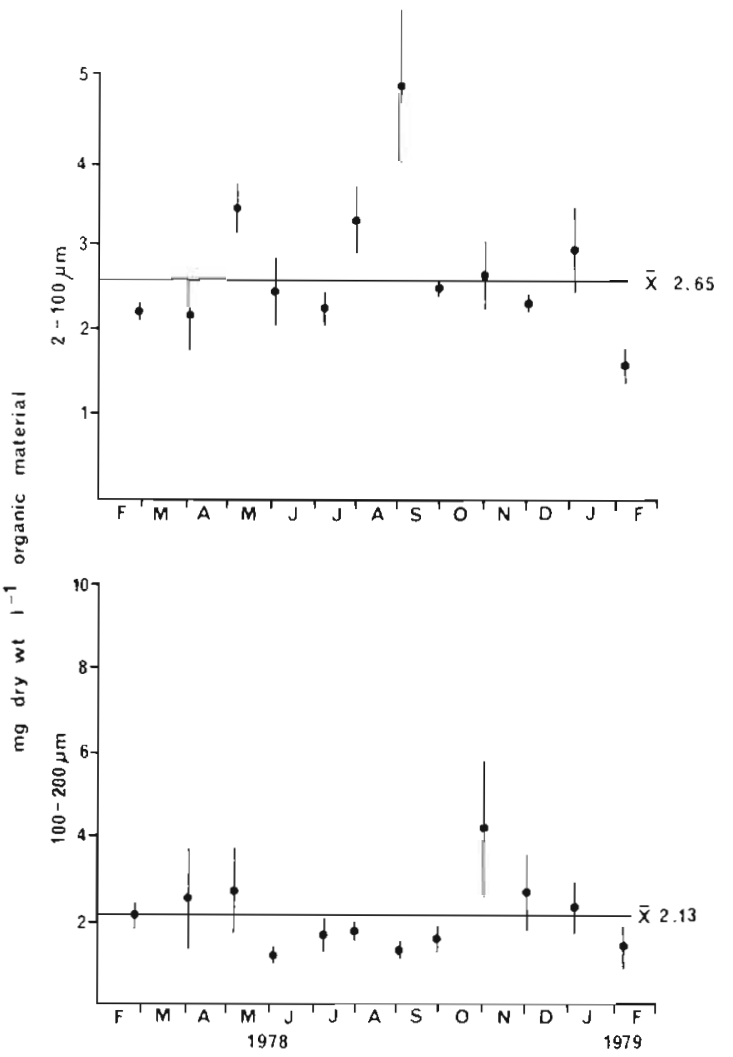

Fig. 2. Changes in weight of particulate organic matter in the diameter ranges $2-100 \mu \mathrm{m}$ and $100-200 \mu \mathrm{m}$ in seawater at Bailey's Cottage during one year. Vertical bars: one standard error

pled and cannot be considered a major constituent in the diet of filter feeders at Bailey's Cottage.

The energy value of organic material $(2-100 \mu \mathrm{m})$ in seawater over the mussel bed is shown in Table 3. Each value represents the mean of 2 or 3 readings on one sample. Twenty-five samples were taken on different days, under varying sea conditions, and different states of tide. There was considerable variability in readings on the same sample and between samples. The energy available in seawater averaged $5.74 \mathrm{~kJ} \mathrm{~g}^{-1}$ AFDW (ash-free dry weight) and inorganic material constituted $53 \%$ of the samples. Paine (1966) has shown that endothermy may occur in samples containing $\mathrm{CaCO}_{3}$ and a correction factor of $0.6 \mathrm{~J} \mathrm{mg}^{-1} \mathrm{CaCO}_{3}$

Table 1. Proportion of organic and inorganic particles in size ranges $<100 \mu \mathrm{m}$ and $100-200 \mu \mathrm{m}$ in seawater over a mussel bed at Bailey's Cottage, February 1978 to February $1979(\mathrm{n}=97)$

\begin{tabular}{|lcccc|}
\hline \multirow{2}{*}{ Amount } & \multicolumn{2}{c}{ Organic } & \multicolumn{2}{c}{ Inorganic } \\
& $<100 \mu \mathrm{m}$ & $100-200 \mu \mathrm{m}$ & $<100 \mu \mathrm{m}$ & $100-200 \mu \mathrm{m}$ \\
\hline Average $\mathrm{mg} \mathrm{l}^{-1}$ & 2.65 & 2.13 & 5.69 & 15.21 \\
One standard deviation & 1.14 & 1.49 & 4.47 & 21.49 \\
Maximum $\mathrm{mg} \mathrm{l}^{-1}$ & 6.95 & 10.29 & 25.76 & 109.12 \\
Minimum $\mathrm{mg} \mathrm{l}^{-1}$ & 1.11 & 0.39 & 0.42 & 0.06 \\
Mean \% of sample & 13.0 & 9.3 & 23.3 & 54.4 \\
\hline
\end{tabular}


may be applied. Assuming that $50 \%$ of the inorganic matter in Table 3 may represent $\mathrm{CaCO}_{3}$ from exoskeletons or shells of marine organisms, the mean energy value may be increased by $6 \%$ to $6.1 \mathrm{~kJ} \mathrm{~g}^{-1}$ AFDW.

Table 2. Number of days on which phytoplankters were recorded during the sampling period and an estimate of their abundance $(2-100 \mu \mathrm{m}$ particle size range)

\begin{tabular}{|lrccc|}
\hline Month & $\begin{array}{c}\text { Days } \\
\text { sampled }\end{array}$ & $\begin{array}{c}\text { Days } \\
\text { algae } \\
\text { recorded }\end{array}$ & $\begin{array}{c}\text { Phytoplankters as } \\
\text { percentage of } \\
\text { sample volume } \\
\text { range }\end{array}$ & $\begin{array}{c}\text { mean } \\
\text { Feb./March }\end{array}$ \\
April & 21 & 5 & $10-60$ & 24 \\
May & 5 & 5 & $6-30$ & 15 \\
June & 5 & 5 & $90-98$ & 95 \\
July & 5 & 0 & - & - \\
July/Aug. & 5 & 1 & - & 50 \\
August & 5 & 8 & $5-80$ & 28 \\
September & 5 & 0 & - & - \\
October & 5 & 0 & - & - \\
November & 5 & 0 & - & - \\
December & 5 & 1 & - & - \\
January & 5 & 5 & $5-50$ & 18 \\
February & 5 & 1 & - & 2 \\
\hline
\end{tabular}

Table 3. Energy values of organic matter $<100$ um particle size) in seawater at Bailey's Cottage. AFDW: ash-free dry weight

\begin{tabular}{|ccc|}
\hline $\mathrm{kJ} \mathrm{g}^{-1}$ dry weight & $\mathrm{kJ} \mathrm{g}^{-1}$ AFDW & $\%$ inorganic \\
\hline 3.81 & 7.71 & 52.0 \\
1.70 & 6.28 & 73.0 \\
2.75 & $10.10^{\circ}$ & 70.5 \\
4.00 & 10.90 & 53.0 \\
0.69 & 1.97 & 64.2 \\
2.38 & 5.74 & 58.6 \\
2.48 & 4.71 & 52.5 \\
0.34 & 1.59 & 78.4 \\
0.39 & 1.71 & 77.5 \\
0.79 & 2.37 & 66.8 \\
4.80 & 10.69 & 55.1 \\
2.06 & 5.21 & 61.1 \\
2.34 & 5.27 & 55.5 \\
1.47 & 3.27 & 55.1 \\
0.37 & 1.14 & 67.7 \\
3.59 & 4.87 & 26.0 \\
4.00 & 6.27 & 34.7 \\
1.79 & 3.82 & 53.2 \\
2.83 & 3.97 & 25.9 \\
3.76 & 6.72 & 44.0 \\
3.61 & 7.83 & 54.0 \\
6.01 & 10.34 & 41.9 \\
2.74 & 4.64 & 40.9 \\
4.63 & 7.39 & 37.3 \\
5.70 & 9.08 & 33.8 \\
\hline 2.76 & 5.74 & 53.3 \\
Mean & & \\
\hline & & \\
\hline
\end{tabular}

\section{Assimilation of Natural Detritus}

The average ration available as food in seawater falls above the range of positive assimilation efficiency in Choromytilus meridionalis when feeding on algal culture. Griffiths (1980) found that the assimilation efficiency fell to zero at a ration of $3 \mathrm{mg}^{-1}$ Dunaliella primolecta and pseudofaeces production was initiated at $6 \mathrm{mg} \mathrm{l}^{-1}$ dry weight. The average ration in seawater (< $100 \mu \mathrm{m}$ particle size range, organic + inorganic) was $8.3 \mathrm{mg} \mathrm{l}^{-1}$.

Figure 3 shows the assimilation efficiency of mussels feeding on natural detritus in the field and in the laboratory. No pseudofaeces production occurred in laboratory experiments. The curve for assimilation efficiency on Dunaliella primolecta is given for comparison. The data were plotted in terms of ration dry weight and AFDW. Laboratory measurements showed
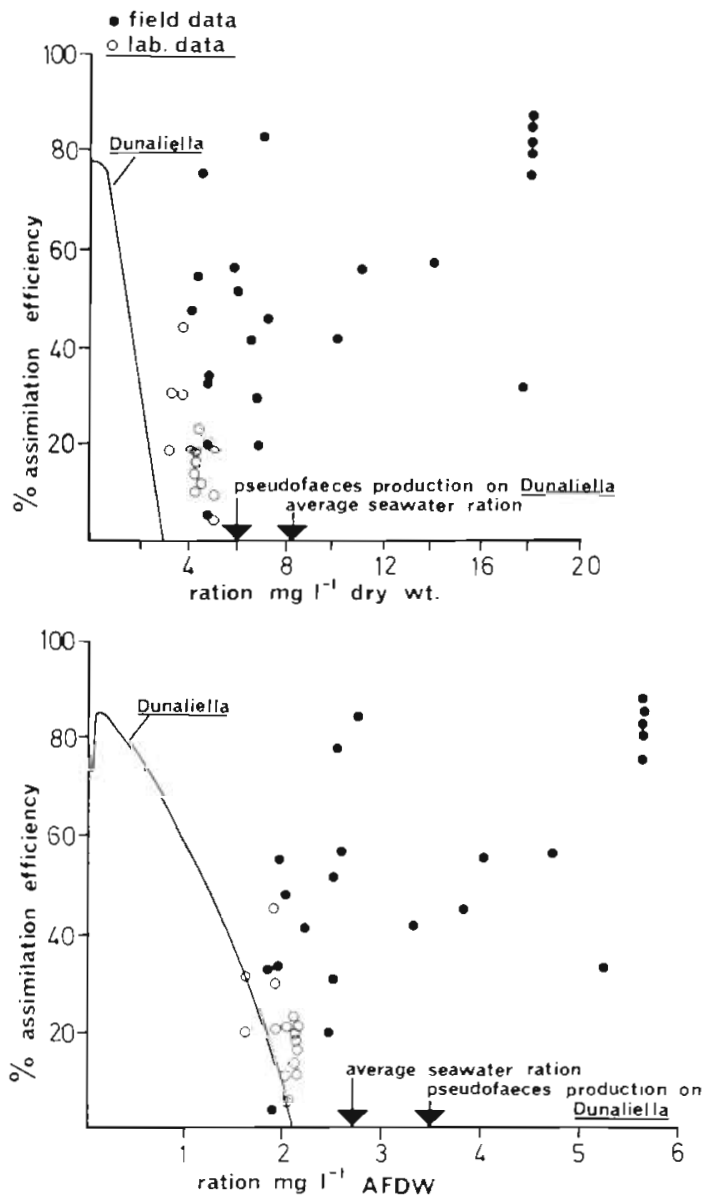

Fig. 3. Choromytilus meridionalis. Assimilation efficiency when feeding on natural detritus in field and laboratory. Curve of assimilation efficiency when feeding on pure Dunaliella primolecta culture given for comparison. Ration levels expressed as particulate dry weight (includes sand) and ash-free dry weight (AFDW); 2-100 $\mu \mathrm{m}$ particle size range 
no detectable difference in the filtration rate of $45 \mathrm{~mm}$ mussels when feeding on detritus or algal culture. An average assimilation efficiency of $40 \%$ (S. E. $=4.1 \%$, $n=37$ ) was obtained over a wide range of ration levels. Variability in the data (maximum efficiency $87 \%$, minimum $4.5 \%$ ) may be a function of experimental technique. Water sampled at any one instant in the field may not reflect that which had been filtered by the mussel during the hour prior to removal from the bed. Furthermore, Foster-Smith (1975) has shown that some retention of ingested material may occur in Mytilus edulis and that this may be mixed with material ingested later and subsequently defaecated. Although the passage of algal cells through the gut of Choromytilus meridionalis may take place within $1 \mathrm{~h}$, sand particles may be egested up to $12 \mathrm{~h}$ after removal of mussels from the natural habitat.

\section{DISCUSSION}

Microscopic examination of the faeces collected from $45 \mathrm{~mm}$ Choromytilus meridionalis in the field showed that they contained large quantities of sand mixed with detritus. The particulate matter in faeces averaged $50 \mu \mathrm{m}$, with particles seldom exceeding $100 \mu \mathrm{m}$ diameter. Examination of the distribution of particulate matter in seawater showed that $13 \%$ of the organic particulate matter occurred in the 2-100 $\mu \mathrm{m}$ size range. However, more than $50 \%$ of the sample consisted of sand particles in the $100-200 \mu \mathrm{m}$ size range. Most of the organic material in this range was attached to the sand grains. Mussels filtering on the shore were observed to eject large quantities of sand in the form of pseudofaeces continuously. On the basis of these observations it was concluded that the bulk of food available to the mussels is represented by particles measuring $2-100 \mu \mathrm{m}$ diameter, and that particles exceeding this size are rejected as pseudofaeces.

Several authors have examined particle size selection in mussels and Bayne et al. (1976) conclude that selective removal does not occur in mussels feeding on natural seawater $(2-100 \mu \mathrm{m}$ particle size range). Although authors such as Vahl (1972, see also review by Bayne et al., 1976) have shown retention of particles below $2 \mu \mathrm{m}$ by the mussel gill, this size range could not be measured in the present study. In view of the large quantities of organic detritus measured in the $2-100 \mu \mathrm{m}$ size range, particles below $2 \mu \mathrm{m}$ are unlikely to form a significant proportion of the diet.

Total organic particulate matter at Bailey's Cottage averaged $5 \mathrm{mg} \mathrm{l}^{-1}$, while an average of $2.65 \mathrm{mg} \mathrm{l}^{-1}$ was considered available to the mussels. Armstrong and Atkins (1951) report $1.6-1.8 \mathrm{mg} \mathrm{l}^{-1}$ particulate organic material in the English Channel, Widdows et al. (1979)
$1.5-1.9 \mathrm{mg} \mathrm{l}^{-1}$ in the Lynher estuary, and Verwey $3 \mathrm{mg}$ $1^{-1}$ available to mussels in the Wadden Sea. Other values measured generally average less than $1 \mathrm{mg} \mathrm{l}^{-1}$ (Jørgensen, 1955). However, it is doubtful that samples taken in the relative calm of deeper waters may be compared with those from the surf zone. Wave action and continual resuspension of the sandy substrate will enhance degradation of organisms and faeces and maintain high levels of organic detritus in the water column

The energy value of organic detritus at Bailey's Cottage averaged $6.1 \mathrm{~J} \mathrm{mg}^{-1}$. Widdows et al. (1979) obtained a value of $23.5 \mathrm{~J} \mathrm{mg}^{-1}$ of food available to Mytilus edulis by analysing the proportions of carbohydrates, lipids and proteins in seawater. At food suspensions of $1.5-1.9 \mathrm{mg} \mathrm{l}^{-1}$ (Widdows et al., 1979) the energy available to $M$. edulis in the Lynher estuary is 35.2-44.7 $\mathrm{J} \mathrm{I}^{-1}$ of seawater. By comparison, the ration available to Choromytilus meridionalis at Bailey's Cottage averages $16.2 \mathrm{~J} \mathrm{I}^{-1}$

The assimilation efficiency on natural detritus proved variable but averaged $40 \%$. Although the method used may over- or under-estimate the true assimilation efficiency in the field, it is clear that Choromytilus meridionalis must be able to maintain a positive energy balance over the normal range of particulate material present in seawater. Experiments using Dunaliella primolecta are thus not directly applicable to natural conditions in the field.

The presence of large quantities of inorganic matter in the bivalve diet appears to be a common phenomenon and Winter (1976) has shown that silt has a beneficial effect on growth in Mytilus edulis. However, this is not merely a result of the presence of silt, but an interaction between total particulate concentration and the ratio of food to silt in the water. Widdows et al. (1979) found that increasing particle concentration results in increasing pseudofaeces production in $M$. edulis, and the ingestion ration remains at a constant level. This limits the amount of food entering the gut, enabling digestion to continue at high particulate concentrations. However, the presence of inorganic particles 'dilutes' the available food ration, and increasing inorganic particulate matter in the diet results in a decline in the energy assimilated. The ratio of organic to inorganic matter is thus important in influencing the energy balance.

In Choromytilus meridionalis a constant filtration rate is maintained over a wide range of ration levels (Griffiths, 1980) and pseudofaecal production must be important in limiting the ingestion ration at high food levels. When feeding on a concentrated food source such as algal culture, with little particulate inorganic material present, pseudofaecal production is not initiated sufficiently early to limit the ingestion ration 
before assimilation efficiency falls to zero. Such a concentrated food source would not be experienced in the field. The presence of particulate inorganic matter may prove an important dietary requirement in $C$. meridionalis in 'diluting' the high organic levels in the sea and allowing a positive assimilation efficiency over a wide range of ration levels.

Acknowledgements. This work was supported as part of the Kelp Bed Research Programme by the South African National Committee for Oceanographic Research.

\section{LITERATURE CITED}

Armstrong, F. A. J., Atkins W. R. G. (1951). The suspended matter of sea water. J. mar. biol. Ass. U. K. 29: 139-144

Bayne, B. L., Thompson, R. J., Widdows J. (1976). Physiology. In: Bayne, B. L. (ed.) Marine mussels, their ecology and physiology. Cambridge University Press, London, pp. 121-206

Conover, R. J. (1966). Assimilation of organic matter by zooplankton. Limnol. Oceanogr. 11: 328-354

Foster-Smith, R. L. (1975). The effect of concentration of suspension and inert material on the assimilation of algae by three bivalves. J. mar. biol. Ass. U. K. 55: 411-418

Fox, D. L., Coe, W. R. (1943). Biology of the Californian seamussel (Mytilus californianus) II. Nutrition, metabolism, growth and calcium depostion. J. exp. Zool. 93: 205-249
Griffiths, C. L., King, J. A. (1979). Some relationships between size, food availability and energy balance in the ribbed mussel Aulacomya ater. Mar. Biol. 51: 141-149

Griffiths, R. J. (1980). Filtration, respiration and assimilation in the black mussel Choromytilus meridionalis. Mar. Ecol. Prog. Ser. 2: 63-70

Hildreth, D. I., Crisp, D. J. (1976). A corrected formula for calculation of filtration rate of bivalve molluscs in an experimental flowing system. J. mar biol. Ass, U. K. 56: $111-120$

Jørgensen, C. B. (1955). Quantitative aspects of filter feeding in invertebrates. Biol. Rev. 30:391-454

Paine, R. T. (1966). Endothermy in bomb calorimetry. Limnol. Oceanog. 11: 126-129

Vahl, J. (1952). Efficiency of particle retention in Mytilus edulis L. Ophelia 10:17-25

Verwey, J. (1952). On the ecology and distribution of cockle and mussel in the Dutch Waddensea, their role in sedimentation and the source of their food supply. Arch. Néerl. Zool. 10; 171-239

Widdows, J. (1978). Combined effects of body size, food concentration and season on the physiology of Mytilus edulis. J. mar. biol. Ass. U. K. 58: 109-124

Widdows, J., Fieth, P., Worral, C. M. (1979). Relationships between seston, available food and feeding activity in the common mussel Mytilus edulis. Mar. Biol. 50: 195-207

Winter, J. E. (1976). Feeding experiments with Mytilus edulis L. at small laboratory scale II. The influence of suspended silt in addition to algal suspension on growth. In: Persoone, G., Jaspers, E. (eds) Proceedings of 10th European symposium on marine biology, Vol. 1, Ostend, Belgium. Universa Press, Wetteren, pp. 565-581

This paper was presented by Professor R. C. Newell; it was accepted for printing on April 12, 1980 